\title{
无机环境材料及其对环境污染物的去除
}

\author{
石伟群 ${ }^{1}$ ，王祥科 ${ }^{2}$
}

(1. 中国科学院高能物理研究所, 北京 100049;2. 华北电力大学 环境科学与工程学院, 北京 102206)

随着人类现代化进程的加快和社会经济的飞速发展, 传统能源消耗不断加快, 气候变化问题日益凸显。现代工 业特别是化学工业的发展在给人们带来便利的同时, 也给与人类生活息息相关的生态环境带来了前所未有的改变, 导致环境问题成为当今世界面临的巨大挑战。为了更好地应对挑战，保护我们赖以生存的家园，广大科研工作者不 断寻求和探索绿色环保并能高效利用的新材料与新技术, 着力解决日益严峻的环境污染问题。在这种形势下, 新型 环境材料与技术受到了广泛重视并得到迅猛发展。

环境材料, 顾名思义, 是针对环境问题而设计发展的材料。环境问题的核心是环境污染, 当前人们密切关注的 环境污染物包括气体污染物、持久性有机污染物和重金属污染物等。近年来随着核工业的崛起和发展, 放射性污染 物也日益受到重视。通过不同手段对环境中的这些污染物进行分离去除是环境污染治理的主要方法。在过去几十 年间, 研究人员不断开发出去除特定污染物的新材料。这些材料种类繁多, 结构多样, 性能各异。研究较多的包括 传统的分子篮 ${ }^{[1]}$, 矿物材料 ${ }^{[2]}$, 以石墨烯、碳纳米管为代表的碳材料 ${ }^{[3]}$, 树脂等高分子材料 ${ }^{[4]}$, 以及近年来颇受学者 重视的金属有机框架材料(MOFs) ${ }^{[5]}$ 和共价有机框架材料(COFs) 等 ${ }^{[6]}$ 。在这些材料当中, 无机材料以其稳定性好、廉 价易得和对环境友好等特点, 在环境污染物的去除分离领域具有广阔的应用前景, 尤其是无机纳米多孔材料近年 来备受青睐。纳米尺寸使得材料不仅具有量子尺寸效应，而且比其它普通材料具有更大的比表面和较多的表面原子， 表现出吸附能力强、在水中分散性好等不同于一般材料的独特性质。多孔性在大幅度提高材料的比表面积、增加 材料与污染物接触面的同时, 还可加快污染物在材料内部的扩散和传输, 使得这类材料在吸附应用中更具潜力和 优势。金属纳米材料、金属氧化物纳米材料、矿物材料等都是无机纳米材料家族的典型代表。

从已有文献来看, 提高污染物去除的效率和选择性一直是无机环境材料领域的研究热点和努力方向。与有机 材料相比, 无机材料虽然具有更高的稳定性, 但是通常对污染物去除效率偏低和选择性不佳, 这主要是因为无机 材料表面缺少活性功能基团。为了克服这一缺点, 常规做法是对无机材料进行功能化修饰。将对目标污染物具有强 结合能力的功能基团通过物理或化学手段修饰在材料表面 ${ }^{[7]}$, 以提高其对污染物的去除能力。在提高选择性方面, 除了在材料表面修饰特异性识别基团 ${ }^{[8]}$ 外, 调节材料的孔道结构, 利用尺寸效应物理篮分污染物 ${ }^{[9]}$ 也是常用和有效 方法。或者通过分子印迹、复合等手段将尺寸效应、键合作用以及静电作用等有机结合起来以提高对目标污染物 的选择性 ${ }^{[10]}$ 。此外, 除了改善分离效率和选择性, 发展在高酸、高碱、高温等苛刻条件下应用的无机环境材料近年 来也逐渐成为研究热点 ${ }^{[11]}$ 。

总而言之, 经过几十年的发展, 无机环境材料研究已经取得了显著进展, 但为了更好地解决日益严峻的环境 问题, 仍然需要广大材料研究者们攻坚克难, 不解努力。

\section{Inorganic Environmental Materials and Their Applications in Pollutant Removal}

\section{SHI Weiqun ${ }^{1}$, WANG Xiangke ${ }^{2}$}

(1. Institute of High Energy Physics, Chinese Academy of Sciences, Beijing 100049, China; 2. College of Enviromental Science and Engineering, North China Electric Power University, Beijing 102206, China)

With the fast advancement of human modernization and rapid development of social economy, traditional energy consumption has been enormously increased and climate change has therefore become a very challenging issue 
for the human being. The development of modern industry, especially the chemical industry, has brought not only convenience to people, but also unprecedented destruction to the ecological environment closely related to human life. Energy and environmental issues have become a global challenge for us today. In order to better deal with the challenges and protect our living homeland, the majority of researchers are constantly seeking and exploring new materials and technologies which are environmentally friendly and can be used efficiently, aiming to solve increasingly serious environmental problems. In current stage, environmental materials and technologies have received ever-increasing attention and are developing rapidly.

Environmental materials, as the name implies, are materials designed and developed for environmental issues. The key issue of environmental problems is environmental pollution. At present, the widely concerned pollutants include gas pollutants, persistent organic pollutants (POPs), and heavy metals. At the same time, with drastic development of nuclear energy industry in the past two decades in China, radioactive pollutants have also received increasing attention. Separation and removal of these pollutants from environment by certain means is an effective and common method for environmental pollution control. Therefore, the key for solving environmental problems is to develop materials and technologies that can effectively remove environmental pollutants. Plenty of versatile materials for specific contaminant removals have been reported over the past few decades. These materials come in a wide variety of functions, with varying structures and performance. Most concerned materials include traditional molecular sieves ${ }^{[1]}$, mineral materials ${ }^{[2]}$, carbon materials such as graphene and carbon nanotubes ${ }^{[3]}$, polymer based materials such as resins ${ }^{[4]}$, metal organic frameworks (MOFs) ${ }^{[5]}$ and covalent organic frameworks (COFs) ${ }^{[6]}$. Among these materials, inorganic materials have broad application prospects in the removal and separation of environmental pollutants due to their stability, low cost and environmental friendliness. In particular, inorganic nanoporous materials have become favorable in recent years. The nanometer size makes nanomaterials not only have quantum size effect, but also possess larger specific surface area and more surface atoms compared to other common materials, thus exhibiting stronger adsorption ability and better dispersibility in aqueous solution. In addition, the porosity of materials greatly enhances the specific surface area and correspondingly increases the contact opportunity between the material and contaminant. Meanwhile, it also improves the diffusion and transportation of contaminants inside the material, elevating the adsorption kinetics. Metal nanomaterials, metal oxide nanomaterials, mineral materials, etc. are typical representatives of inorganic nanomaterial family.

Based on the published works, many efforts in the field of inorganic environmental materials focused on improving the removal efficiency and selectivity toward one or more target pollutants. Inorganic materials have higher stability than organic materials, but possess low removal capacity and poor selectivity, due to lacking of active functional groups on the surface. Functionalization of inorganic materials should be a reasonable approach to overcome this drawback. It is well known that functional groups with strong binding or coordination ability to the target contaminant decorated on the surface of material by physical or chemical means can greatly improve the adsorption performance of inorganic materials ${ }^{[7]}$. Moreover, besides modifying the specific recognition group on the surface of the material ${ }^{[8]}$, adjusting the pore structure of material and physically screening contaminants by the size effect $^{[9]}$ are always common and effective. It is also promising to combine size effects, bonding and electrostatic interactions by means of molecular imprinting or composition ${ }^{[10]}$. Besides, developing inorganic environmental materials used under harsh conditions ${ }^{[11]}$, such as high acid, high alkali, and high temperature, is becoming a research hot topic in recent years.

In all, after decades of development, researches on inorganic environmental materials have made significant progress, whereas most of materials are still not satisfactory for industrial applications. In order to better solve the increasingly serious environmental problems, it is still necessary for the material researchers to overcome difficulties and make continuous efforts. 


\section{References:}

[1] SHI W M, FU Y W, JIANG W, et al. Enhanced phosphate removal by zeolite loaded with Mg-Al-La ternary (hydr)oxides from aqueous solutions: performance and mechanism. Chem. Eng. J., 2019, 357: $33-44$.

[2] ALSHAMERI A, HE H P, ZHU J X, et al. Adsorption of ammonium by different natural clay minerals: characterization, kinetics and adsorption isotherms. Appl. Clay Sci., 2018, 159: 83-93.

[3] SHAO D D, JIANG Z Q, WANG X K, et al. Plasma induced grafting carboxymethyl cellulose on multiwalled carbon nanotubes for the removal of $\mathrm{UO}_{2}{ }^{2+}$ from aqueous solution. J. Phys. Chem. B, 2009, 113(4): 860-864.

[4] NAUSHAD M, ALOTHMAN Z A, AWUAL M R, et al. Adsorption of rose Bengal dye from aqueous solution by amberlite Ira-938 resin: kinetics, isotherms, and thermodynamic studies. Desalin Water Treat., 2016, 57(29): 13527-13533.

[5] LI J, WANG X X, ZHAO G X, et al. Metal-organic framework-based materials: superior adsorbents for the capture of toxic and radioactive metal ions. Chem. Soc. Rev., 2018, 47(7): 2322-2356.

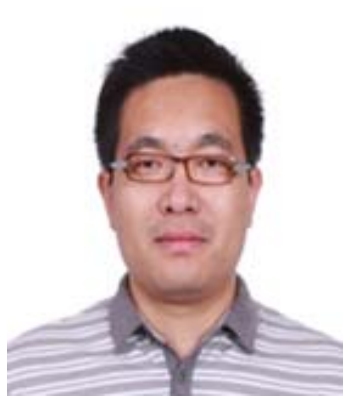

石伟群，研究员，2019 年获 国家杰出青年科学基金资 助。现为中国化学会核化学 与放射化学分会及中国核 学会铜系物理与化学分会 常务理事、中国有色金属学 会熔盐化学与技术专业委 员会副主任委员, 并担任 Journal of Nuclear Science and Technology 的国际顾问编委。长期从事核 燃料循环化学与钶系元素化学相关基础研究。

E-mail: shiwq@ihep.ac.cn
[6] YU J, YUAN L, WANG S, et al. Phosphonate-decorated covalent organic frameworks for actinide extraction: a breakthrough under highly acidic conditions. CCS Chemistry, 2019, 1(3): 286-295.

[7] YUAN L Y, LIU Y L, SHI W Q, et al. A novel mesoporous material for uranium extraction, dihydroimidazole functionalized SBA-15. J. Mater. Chem., 2012, 22(33): 17019-17026.

[8] YUAN L Y, ZHU L, XIAO C L, et al. Large-Pore 3D cubic mesoporous (KIT-6) hybrid bearing a hard-soft donor combined ligand for enhancing U(VI) capture: an experimental and theoretical investigation. ACS Appl. Mater. Inter., 2017, 9(4): 3774-3784.

[9] CUI X L, CHEN K J, XING H B, et al. Pore chemistry and size control in hybrid porous materials for acetylene capture from ethylene. Science, 2016, 353(6295): 141-144.

[10] WANG L, SONG H, YUAN L Y, et al. Effective removal of anionic $\mathrm{Re}(\mathrm{VII})$ by surface-modified $\mathrm{Ti}_{2} \mathrm{CT}_{x}$ MXene nanocomposites: implications for Tc(VII) sequestration. Environ. Sci. Technol., 2019, 53(7): 3739-3747.

[11] WU Z Y, LI C, LIANG H W, et al. Carbon nanofiber aerogels for emergent cleanup of oil spillage and chemical leakage under harsh conditions. Scientific Reports, 2014, 4: 4079.

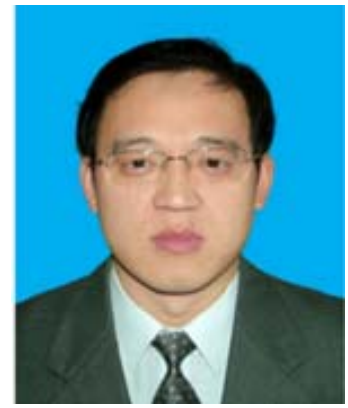

王祥科, 教授, 2003 年入选 中科院百人计划“引进海外 杰出人才”, 2012 年获国家 杰出青年科学基金资助, 2015 年被评为教育部长江 学者特聘教授, 2017 年入 选中组部万人计划领军人 才。主要从事三废治理、纳米材料在废水处理、 等离子体技术应用、环境污染检测和治理中的应 用等方面的研究工作。

E-mail: xkwang@ncepu.edu.cn 